\title{
A DETECTOR FOR SUB-SURFACE CRACKS
}

L. E. Goodwin

Instrument Development Division

August 1954

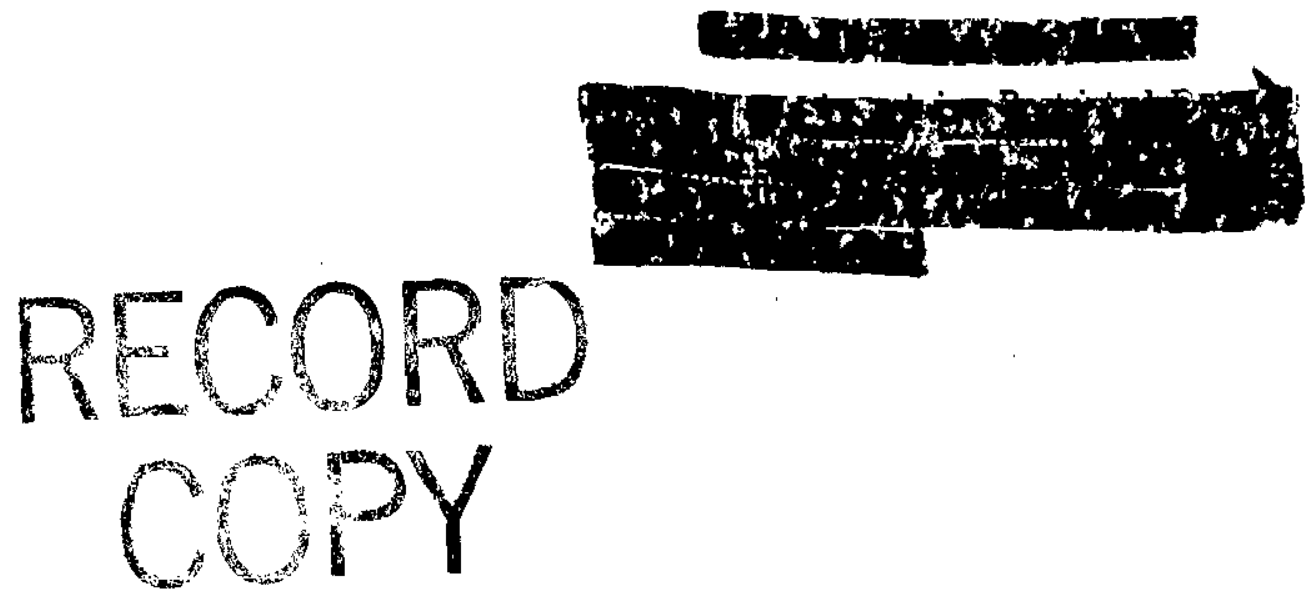

DO POT RIELEASE

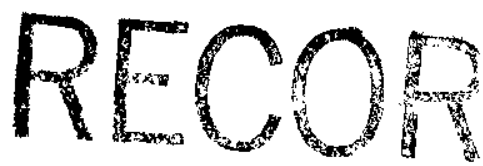

FROM FILE

E. I. du Pont de Nemours \& Co.

Explosives Department - Atomic Energy Division

Technical Division - Savannah River Laboratory 


\title{
A DETECTOR FOR SUB-SURFACE CRACKS
}

\author{
by
}

I. E. Goodwin

Instrument Development Division

August 1954

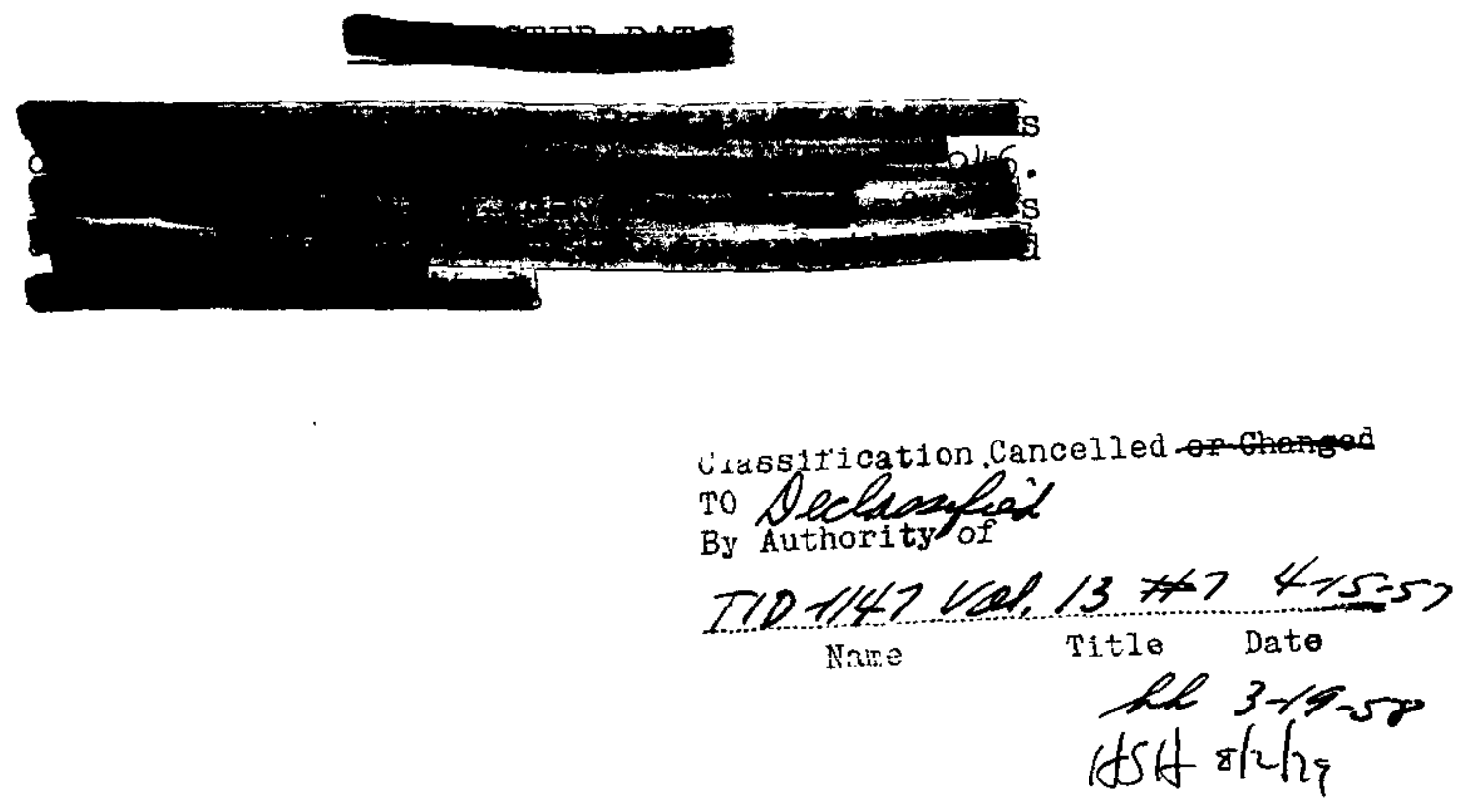

E. I. du Pont de Nemours \& Co.

Explosives Department - Atomic Energy Division

Technical Division - Savannah River Laboratory

Contract AT (07-2)-1 with the

United States Atomic Energy Commission 
INTERNAL DISTRIBUTION

1-5. Document Custodian

6. L. Squires - H. Worthington

7. J. C. Woodhouse

8. R. M. Evans - B. H. Mackey

9. W. C. Kay - M. H. Sm1th

10. J. B. Tinker

11. D. F. Babcock

12. J. A. Burns

13. W. P. Overbeck

14. T. C. Evans

15. P. D. Deans

16. K. W. Millett

17. H. H. Dickerson

18. R. D. McCrosky

19. K. E. Plumlee

20. E. C. Laing

21. H. J. Bowman

22. PRD File

AEC, SROO, Augusta, Ga. W1imington AED

W1lmington Engineering Department

Savannah R1ver Plant

11
11
11
11
11
11
11

23. M. H. Wahl - C. W. J. Wende Savannah RIver Laboratory

24. J.W. Croach

25. J. N. Wilson

26. A. H. Dexter

27. I. E. Goodwin

28. P. H. Permar

29. V. I. MontenyohI

30. M. McKeehan

31-45. TIS File

46. TIS File Record Copy

\section{EXTERNAL DISTRIBUTION}

47. AF Plant Representative, Seattle

48. AF Plant Representative, Wood-Ridge

49. American Machine and Foundry Company

50-57. Argonne National Laboratory

58-62. Atomic Energy Commission, Washington

63. Babcock and W1lcox Company

64. Battelle Memorial Institute

65. Bendix Aviation Corporation

66-68. Brookhaven National Laboratory

69. Brush Beryllium Company

70. Bureau of Mines, Albany

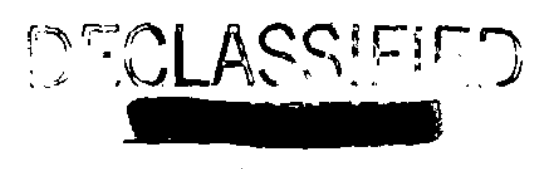




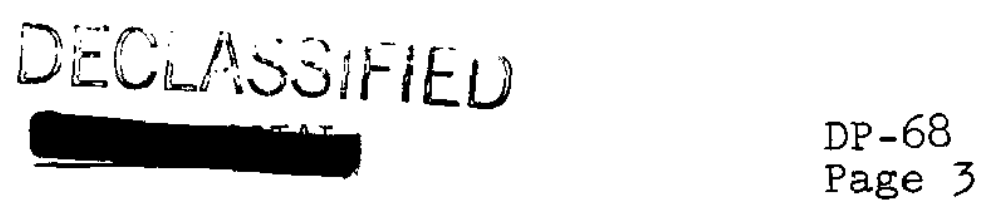

METALLURGY \& CERAMICS

\section{EXTERNAL DISTRIBUTION (Continued)}

71. Bureau of Ships

72-73. Carbide and Carbon Chemicals Company (K-25 Plant)

74-79. Carbide and Carbon Chemicals Company (ORNL)

80. Chicago Patent Group

81. Commonwealth Edison Company

82. Detroit Edison Company

83. Dow Chemical Company (Rocky flats)

84. Duquesne Light Company

85. Foster Wheeler Corporation

86-88. General Electric Company (ANPD)

89. General Electric Company (APS)

90-101. General Electric Company, Richland

102. Hanford Operations office

103. Iowa State College

104-107. Knolis Atomic Power Laboratory

108-110. Los Alamos Sclentific Laboratory

111. Malinckrodt Chemical Works

112. Materials Laboratory (WADC)

113. Monsanto Chemical Company

114. Mound Laboratory

115. National Advisory Committee for Aeronautics, Cleveland

116. National Bureau of Standards

117. National Lead Company of Ohio

118. Naval Research Laboratory

119. New Brunswick Laboratory

120. Newport News Shipbullding and Dry Dock Company

121. New York Operations Office

122-124. North American Av1ation, Inc.

125. Nuclear Development Associates, Inc.

126. Nuclear Metals, Inc.

127. Pacific Northwest Power Group

128. Patent Branch, Washington

129-132. Phillips Petroleum Company (NRTS)

133. Power Plant Laboratory (WADC)

134-135. Pratt \& Whitney Aircraft Division (Fox Project)

136. Sylvania Electric Products, Inc.

137. Tennessee Valley Authority (Dean)

138-139. University of California Radiation Laboratory, Berkeley

140-141. University of California Radiation Laboratory, Livermore

142. Vitro Laboratories

143. Walter Kidde Nuclear Laboratorles, Inc.

144-147. Westinghouse Electric Corporation

148-162. Technical Information Service, Oak Ridge

\section{DECLAUvil :LD}




\section{ABSTRACT}

An instrument was developed to detect cracks within 1/8.1nch of the surface of cylindrical uranium fuel slugs. The instrument measures changes in eddy currents that are induced at a frequency of $2 \mathrm{KC}$.

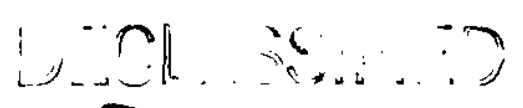




\section{DECLASSIFIED}

TABLE OF CONTENTS

INTRODUCTION.

SUMMARY

PATENT SITUATION . . . . . . . . . . . . . . . . 6

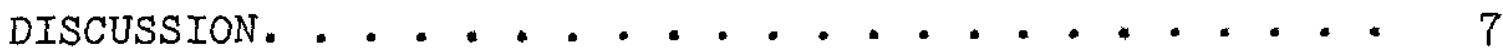

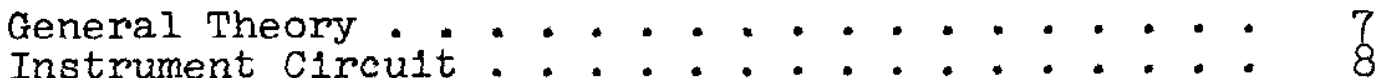

Description . ................. 8

Initial Adjustments . . . . . . . . . . . 9

Associated Equipment . . . . . . . . . . . 9

Operating Instructions . . . . . . . . . 9

Initial Results . . . . . . . . . . . . . . 11

BIBLIOGRAPHY . . . . . . . . . . . . . . . 12

APPENDIX - Maintenance ............. . . 24

\section{LIST OF FIGURES}

Figure 1 Block Diagram of Sub-Surface Crack Detector . 13 Figure 2 Circuit Diagram of Sub-Surface Crack

Detector........... . . 14

Figure 3 Drawing of Coll Assembly . . . . . . . * . 15

Figure 4 Chart Records of Slugs Chosen for Sectioning. 16

Flgure 5 Photograph: Slug 6519-2-25 Second Defect : 17

Flgure 6 Photograph: Slug 6519-2-25 Third Defect. : 18

Figure 7 Photograph: Slug 7828-1-25 Defect. . . . 19

Figure 8 Photograph: Slug 8051-3-17 Defect. . . . . 20

Flgure 9 Photograph: Equipment Assembly . . . . . 21

F1gure 10 Photograph: Equipment Chassis . . . . . . 22

Figure 11 Photograph: Equipment Chassis . . . . • 23 


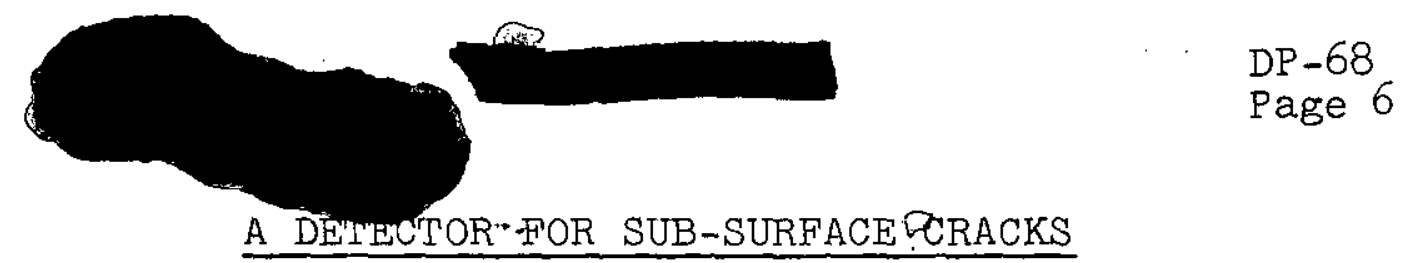

\section{INTRODUCTION}

Br.

A crack in a cylindrical uranium slug may produce a fallure under the conditions of pile irradiation; therefore, a non-destructive method of detecfing such cracks is desired. Previous work by others (1) had indicated that a commercial instrument called the Cyclograph(2) could be used to detect sub-surface cracks. However, the poor response of the instrument at low frequencies limited the depth of examination in the slug. This report covers an adaptation of the Cyclograph that is not subject to the above limitation.

\section{SUMMARY}

An instrument was developed to detect cracks in bare cylindrical uranium slugs. Eddy currents are induced in the slug by passing it through the colls of an osclilator operating at $2 \mathrm{KC}$. Cracks or inhomogene1ties in the slug change the magnitude of the current flowing in the coils by interfering with the eddy currents. The change in current is amplified and presented on a recorder. An initial evaluation of the instrument verifled that it detects sub-surface cracks. A more complete evaluation is forthcoming in Report No. DP-67.

\section{PATENT SITUATION}

The Cyclograph is covered by Patent No. 2,477,384, dated July 26, 1949. (3) The detector for sub-surface cracks does not appear to infringe any of the claims made in the Cyclograph patent. 


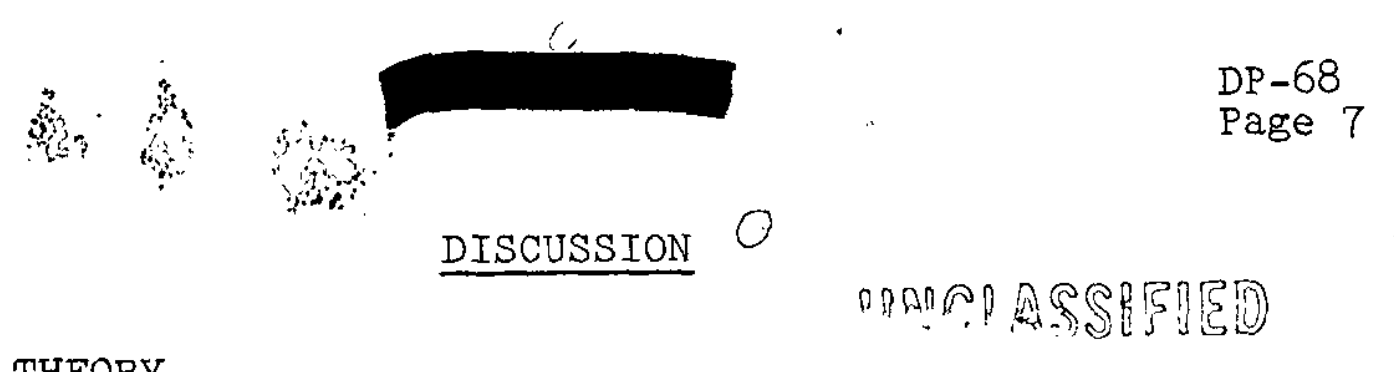

GENERAL THEORY

The detector for sub-surface cracks is basically a sensitive push-pull oscillator of which the test colls are a part. Its operating frequency is determined by the test coils, which are wound for the desired frequency. When the oscillator is operating, a magnetic field is set up in the test colls. Under this condition, both the energy output of the oscillator and the amplitude of oscillation are constant. When a uranium slug is placed in the test colls, the magnetic field induces circumferential eddy currents in the slug, the magnitude of the eddy currents being dependent upon the conductivity of the slug and the frequency of osciliation. The induced eddy currents cause energy to be lost from the osclilator, due to I2R losses, and change the amplitude of oscillation. The energy losses may be so large that the positive feedback must be increased in order to maintain oscillation. The energy losses change the effective impedance of the test colls.

If the uranium slug is homogeneous throughout its entire length, the slug may be moved back and forth within the coils without affecting the amplitude of oscillation. At the location of a crack, the conductivity of the sample is changed, eddy current losses are less, and the amplitude of oscillation increases. This increase is recorded as a deviation from the almost straight-line response given by a normal, uniform slug.

The coll arrangement used is most sensitive to open longltudinal cracks. Seams, short or shallow flaws, small radial cracks, and pinholes affect the circumferential currents to a lesser degree, and the resulting fleld distortion produces relatively small changes in the amplitude of oscillation.

The frequency is chosen so that the effective depth to which the eddy currents penetrate is sufficient to detect cracks that lie within 1/8-inch of the surface. The depth at which the magnitude of the current decreases by a factor of $1 / e$, or about 36.9 per cent of its value at the surface, is given approximately by,

$$
d=\frac{1}{\sqrt{\pi f \mu \sigma}}
$$

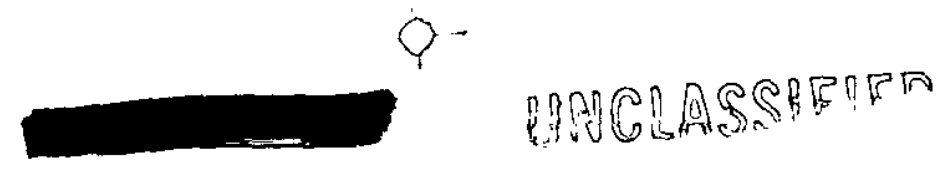




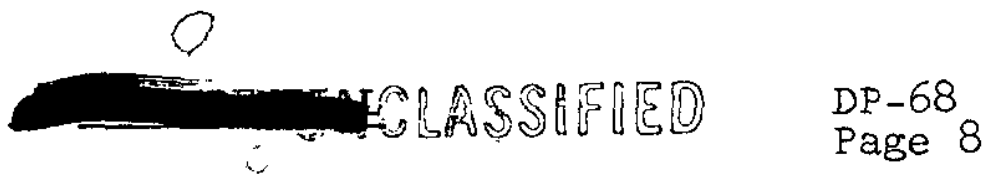

Where: $\sigma=$ conductivity in mhos $/$ meter $=3.47 \times 10^{6} \mathrm{mhos} / \mathrm{m}$

$\mu=$ permeability in henrys $/$ meter $=4 \times 10-7$ henry $/ \mathrm{m}$

$f=$ frequency of oscillation in cycles $/$ second $=2000$ cycles/sec

$\mathrm{d}=$ effective depth of penetration $=6.12 \times 10^{-3}$ meters $(=0.241$ inch. $)$

Thus, the depth of penetration is sufficient to give good sensitivity to defects occurring within the first $1 / 8$-inch.

\section{INSTRUMENT CIRCUIT}

Figure 2 is a circuit diagram of the electronics with the exception of the Brown recorder. The assembled equipment is shown in Figure 9 .

Description

Power Supply The power supply consists of a conventional full-wave rectifier with an output of 380 volts under load. There is also a regulated 220-volt output.

Oscillator The oscillator, of which the detecting test colls are a part, is a push-pull oscillator. The coils are bifilar wound with 400 turns of No. 36 Formvar coated wire. Coll specifications appear in Figure 3. These coils give a frequency of operation of approximately 2 kilocycles.

Cathode Follower The cathode follower acts as a buffer stage between the oscillator and the amplifier.

Amplifier The amplifier consists of two 6V6's in pushpull.

Detector The output of the amplifier is fed to a balanced detector. Two $6 \mathrm{H} 6$ tubes are used for this purpose.

Second Cathode Follower The second cathode follower. serves as a buffer between the detector and the recorder. One-half of the second cathode follower output stage is used to supply a reference voltage so that the output may be adjusted to buck out most of the DC component.

Recorder The recorder (Model No. $153 \times 18 \mathrm{~V}-\mathrm{X}-118 \mathrm{~N} 4$ ) 18 a Brown recorder with a 1 -second response and a chart speed of 8 inches per minute.

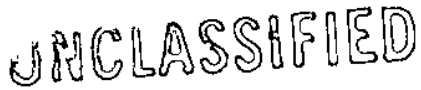




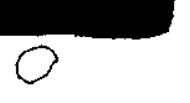

DP -68

Page 9

Initial Adjustments

bog?

Feedback Controls The coarse feedback control (refer to Figure 10) consists of two ganged switches. It controls the amount of positive feedback in the osc11lator section of the clrcult. This is a chassis adjustment, not avallable to the operator.

The fine feedback control is a $10,000 \mathrm{ohm}$ helipot common to the cathode circuit of each triode section of the 6SN7 oscillator tube. It is an external control located on the front of the upper panel.

Chassis Adjustments, (A11 chassis adjustments are made before installation.)

a. 2,000 ohm pot - this allows the bias of one of the 6 V6 tubes to be adjusted so that the pair may be balanced.

b. $100,000 \mathrm{ohm}$ pots - these two ganged pots provide gain control. They control the input to the $6 \mathrm{~V} 6$ tubes.

c. $200 \mathrm{ohm}$ pot - this pot adjusts the DC output of the cathode follower so that the range of the recorder (0-100 millivolts) is not exceeded. This pot is a sensitivity control and may be adjusted, if required. Too much sensitivity, however, increases instablitty and does not improve the indication caused by a crack.

d. 500,000 ohm pot - this pot controls the amount of regulated output voltage. It is adjusted to give 220 volts in the output of the regulator. (Refer to Figure 11.)

Associated Equipment In addition to the electronic equipment, a semi-automatic feeder, designed and built at ANL, was provided to feed the slugs through the concentric coil at a uniform rate. The feeder with the coil assembly in place is shown in Figure 9.

Operating Instructions

Terminals

a. Input The input terminal to the oscillator (refer to Figure 1 for a block diagram of the instrument) is a Jones plug located on the front of the top panel. The test colls supplied with the instrument are plugged into this Jones connector. The test colls must be firmly connected to the input cable.

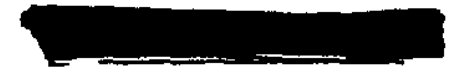




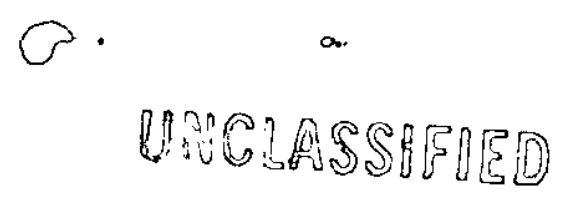

DP -68

Page 10

b. Output The output terminal from the detector is located on the back of the chassis of the top panel. The output terminal should be connected with the proper polarity to the input terminal of the Brown recorder.

\section{Starting Procedure}

a. There are two power cables at the back of the cabinet. One cable supplies power for the Brown recorder and the other cable supplies power for the remaining circuitry. Plug both power cables into a nominal 115 volt, 50 to 60 cycle power line.

b. Insert a slug in the coils. The coils should be about half-way between the ends of the test sample.

c. Throw the power switch to the "on" position. This is the sole switch on the first panel above the Brown recorder.

d. Open the recorder door. There is a knob to the right of the chart paper. Turn this knob counterclockwise and pull. Almost the entire recorder assembly swings out of the case. At the back of the recorder assembly, there is a switch on the far right just below center. Throw this switch to the "on" position. Swing the recorder assembly back into position and turn the knob mentioned above in a clockwise direction to lock the assembly in its case.

e. Allow several minutes for the equipment to warm up. Although the unit can be used after 2 or 3 minutes of warm-up, it is desirable to allow about 10 minutes warm-up time, if possible.

f. Throw the sw1tch on the front of the recorder assembly to the "on" position. This switch is located on the right of the chart paper.

g. Adjust the knob on the top panel unt1l the recorder pin is in the center of the chart paper. The crack detector is now ready for operation.

h. With the co1l properly adfusted in the feeder, start the feeder by turning the switch located on top of the metal box on the feeder. Run the slugs through the concentric coll, end to end, allowing as little air gap as possible between adjacent slugs. This reduces end effects. Choose one slug as a standard. Run this slug through the coil periodically to make sure the instrument is stable. (Refer 
to the discussion below-for an analysis of the recordings.)

\section{INITIAL RESULTS}

of the approximately 500 slugs run through the instrument, 12 slugs were chosen for further examination on the basis of deviations from the response given by a normal slug. The 12 slugs were retested three times and three were chosen for sectioning on the basis of their pronounced deviation from the nearly straight response given by a normal slug. Flgures $4,5,6,7$, and 8 present strip chart recordings and photographs of the cracks. Slugs $B$, $F$, and $G$ were chosen for sectioning. Slugs A through $E$ gave almost identical chart Indications. One of these slugs (B) was. sectioned to determine the cause of the six peaks. The position of each peak was measured from the numbered end on the chart paper, and the position along the length of the slug corresponding to the peaks was marked using the conversion factor,

the length of the slug

The other two slugs were marked in a similar manner for their single indications. In the eight sections that were made, only four defects were actually found. The four cuts which revealed no defect were four of the six made on Slug $B$. It cannot be said conclusively that there were no cracks at the location where the section was made because the crack may have been destroyed or missed in the sectioning process.

A more extensive evaluation of the instrument can be found in DP -67 .

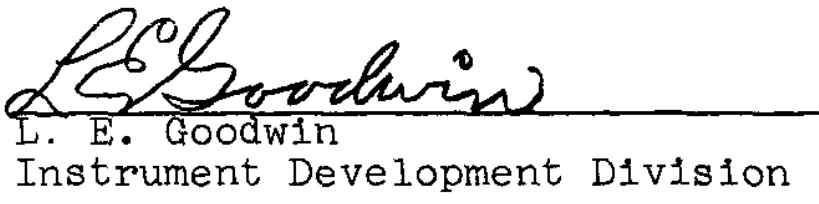




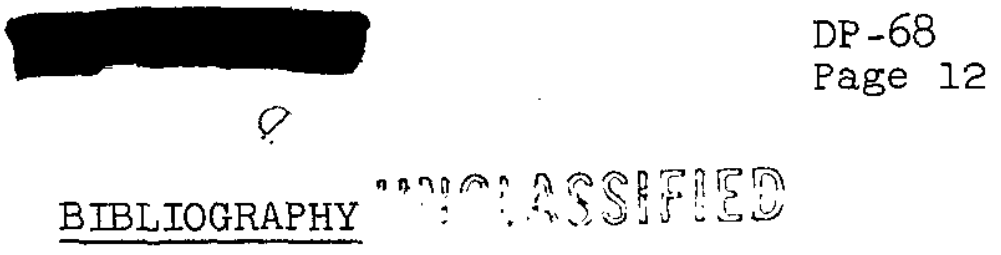

1. ANL-5161, Lemont, Illino1s, Argonne National Laboratory (1954) (Secret).

2. Cyclograph Instruction Manual. Englewood, N. J., J.W. Dice Company.

3. Mann, E. R. \& Beste, H. E. (DuMont Co.). Manufactured by J. W. D1ce Company, Patent No. 2,477,384, July 26, 1949.

4. Romo, Simon \& Whinnery, John R. Flelds and Waves in Modern Radio. John Wiley and Sons, Inc., p. 206 (I952).

5. McKeehan, M. Evaluation of the Sub-Surface Crack Detector. DP-67, 1954 (Confldential) 


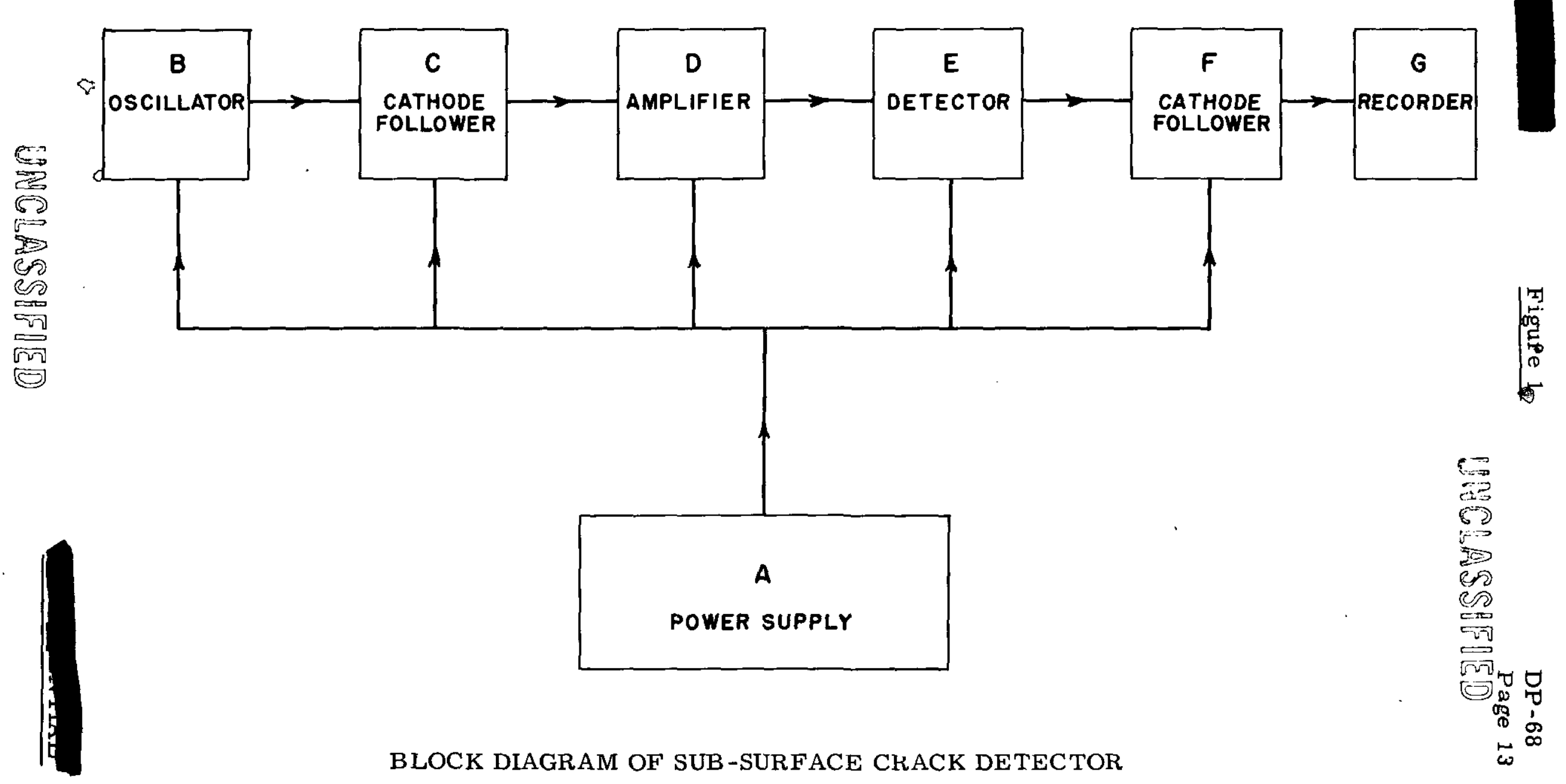




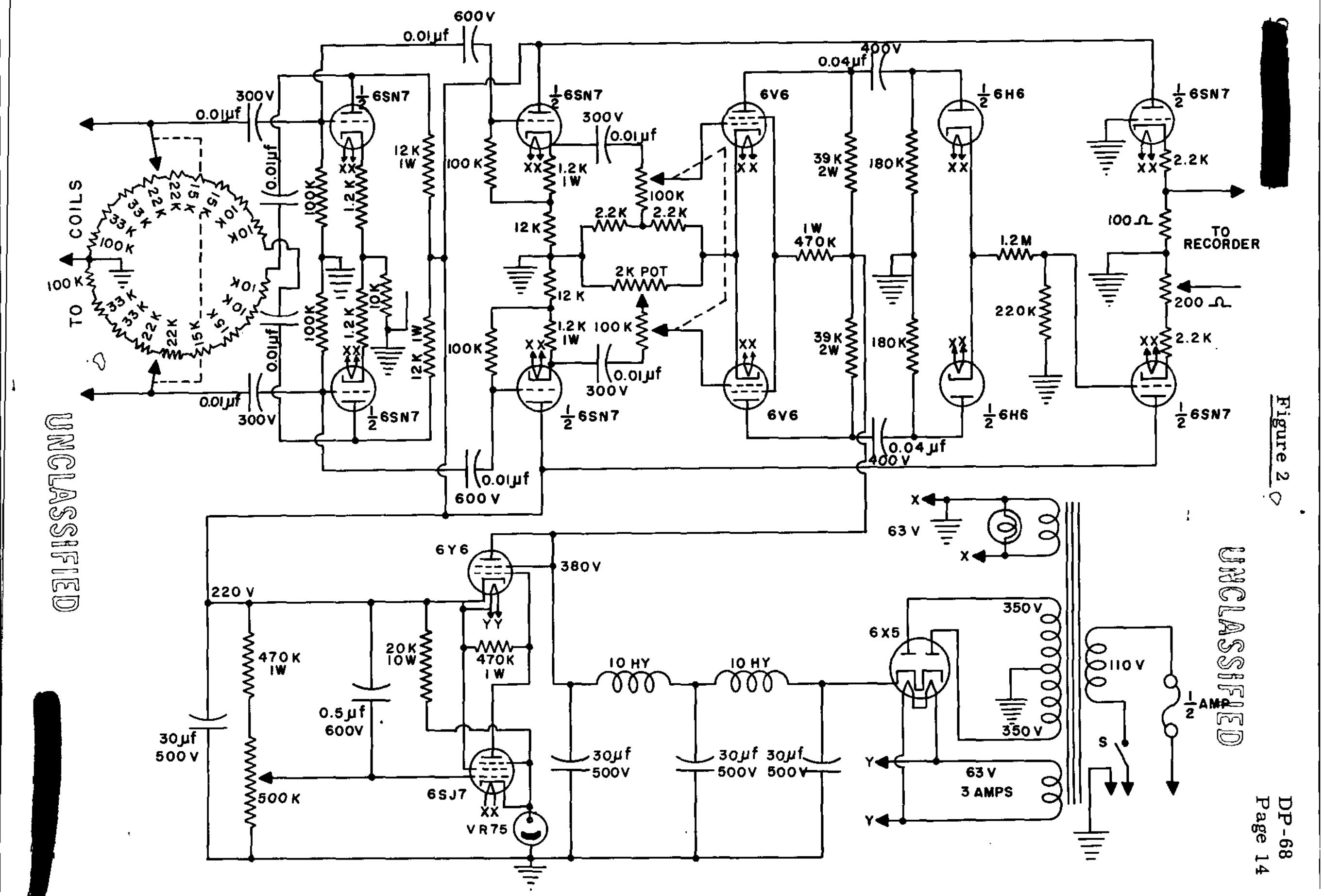

CIRCUIT DIAGRAM OF SUB-SURFACE CRACK DETECTOR 

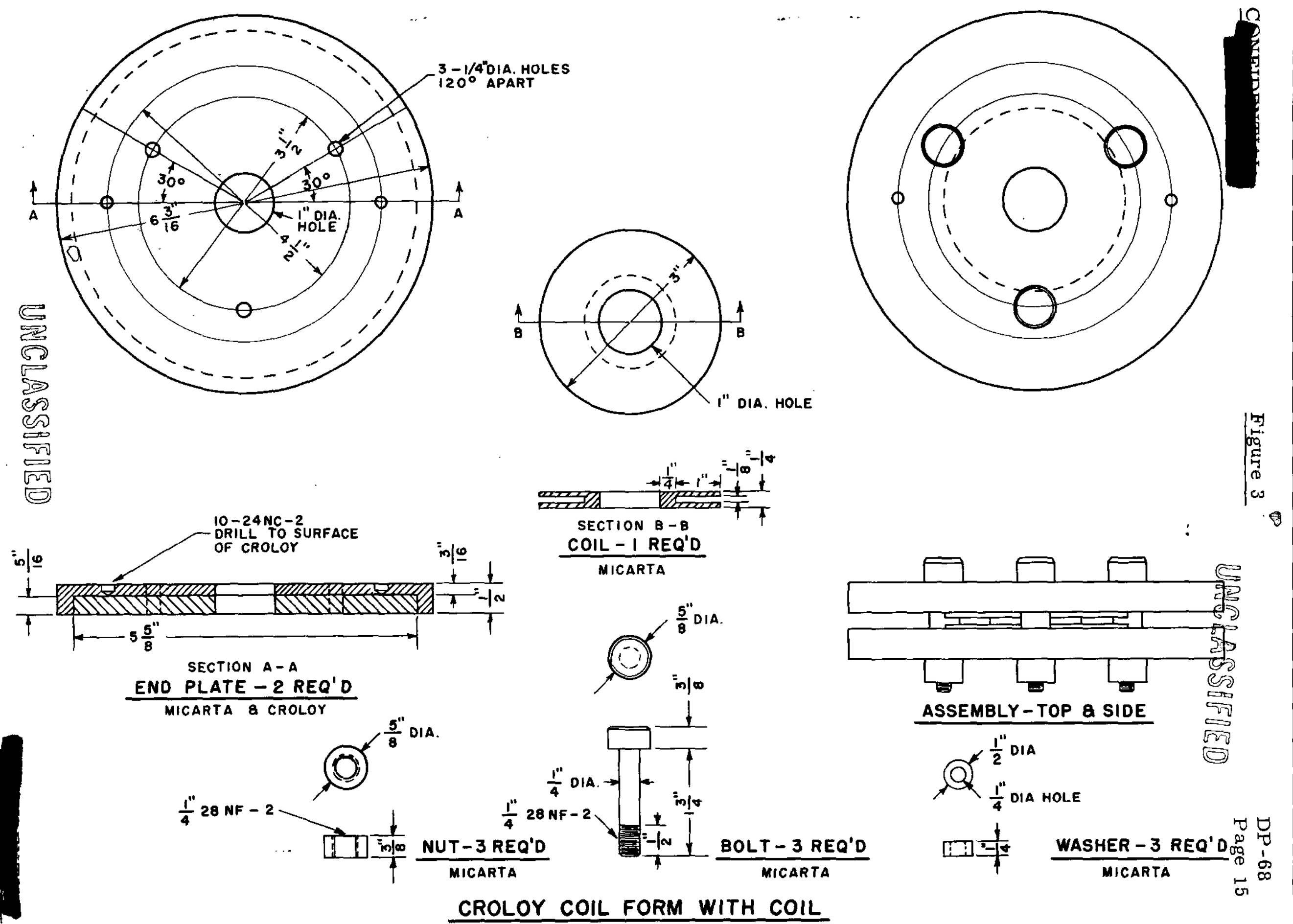


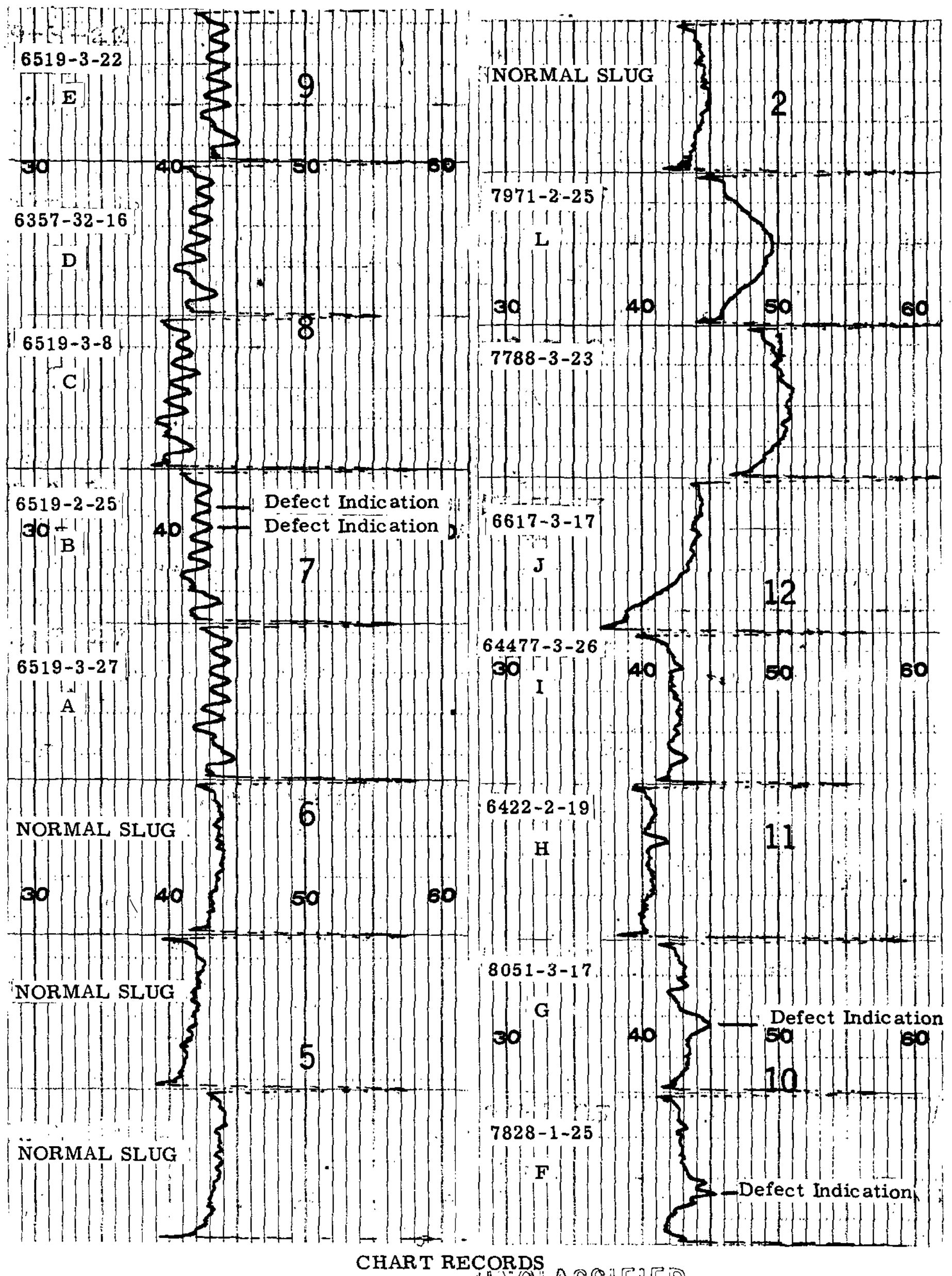




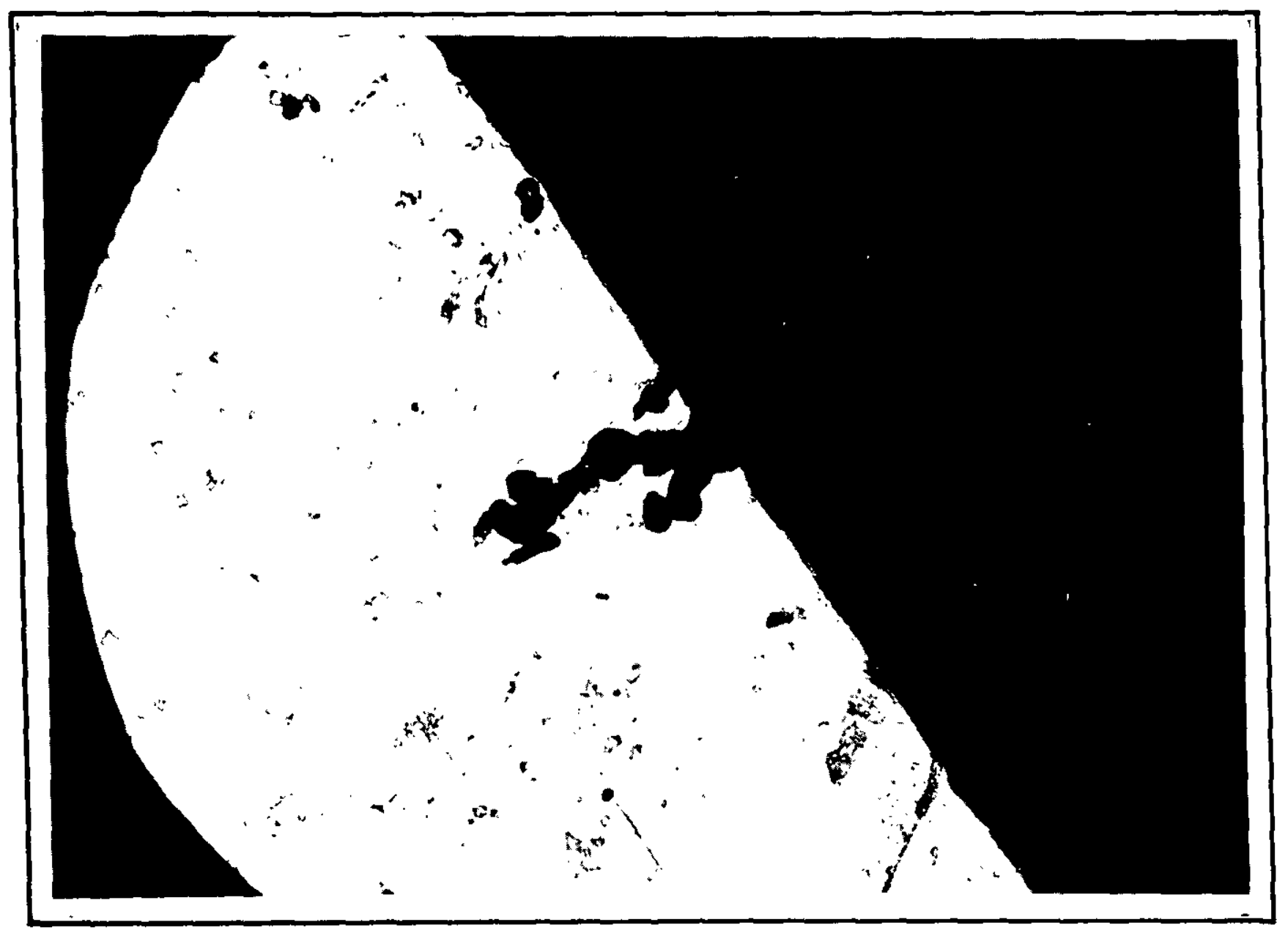

SLUG 6519-2-25 SECOND DEFECT FROM NUMBERED END MAGNIFIED 250 TIMES

$\ddot{c}$ 


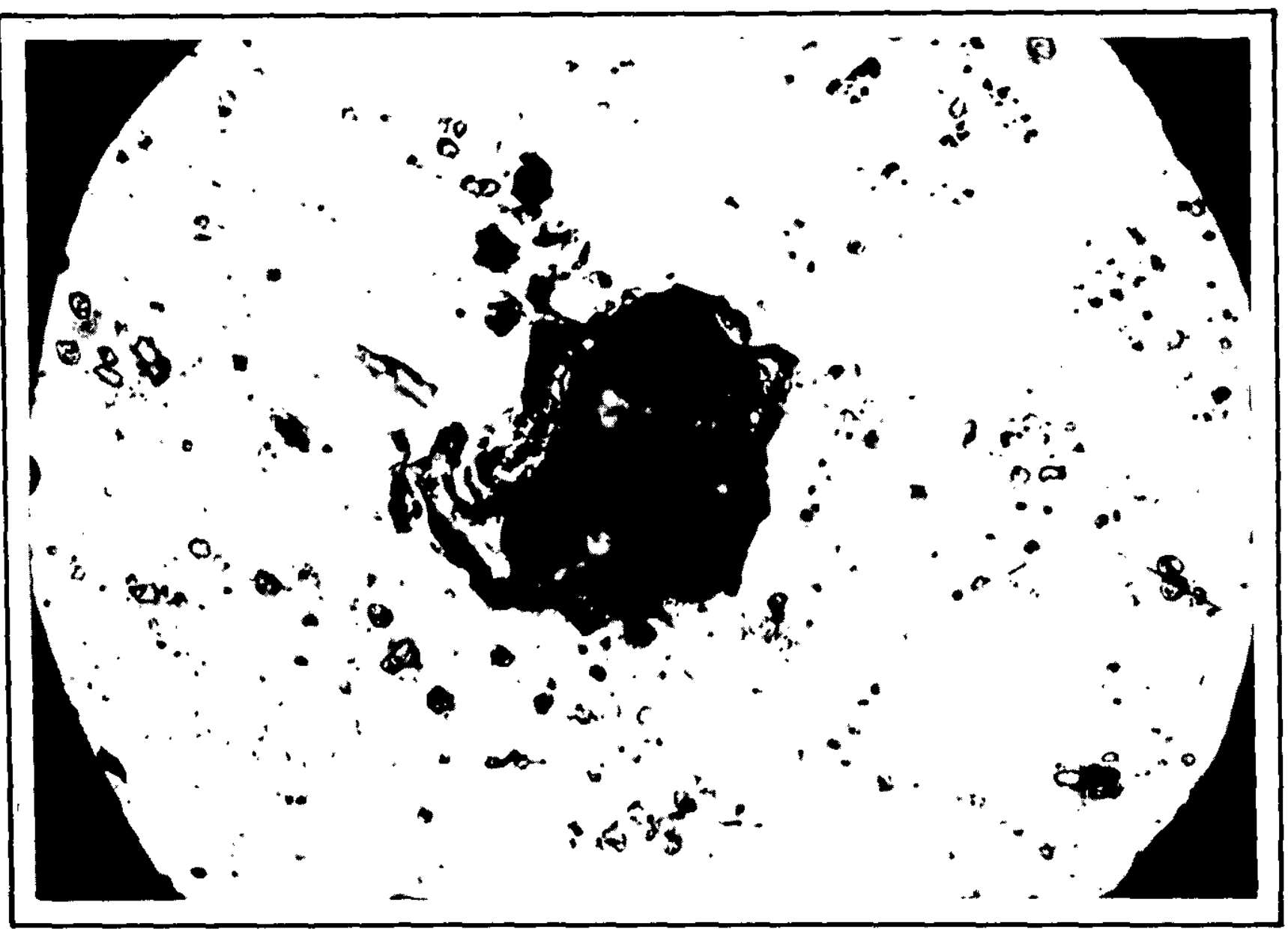

SLUG 6519-2-25 THIRD DEFECT FROM

NUMBERED END MAGNIFIED 250 TIMES 


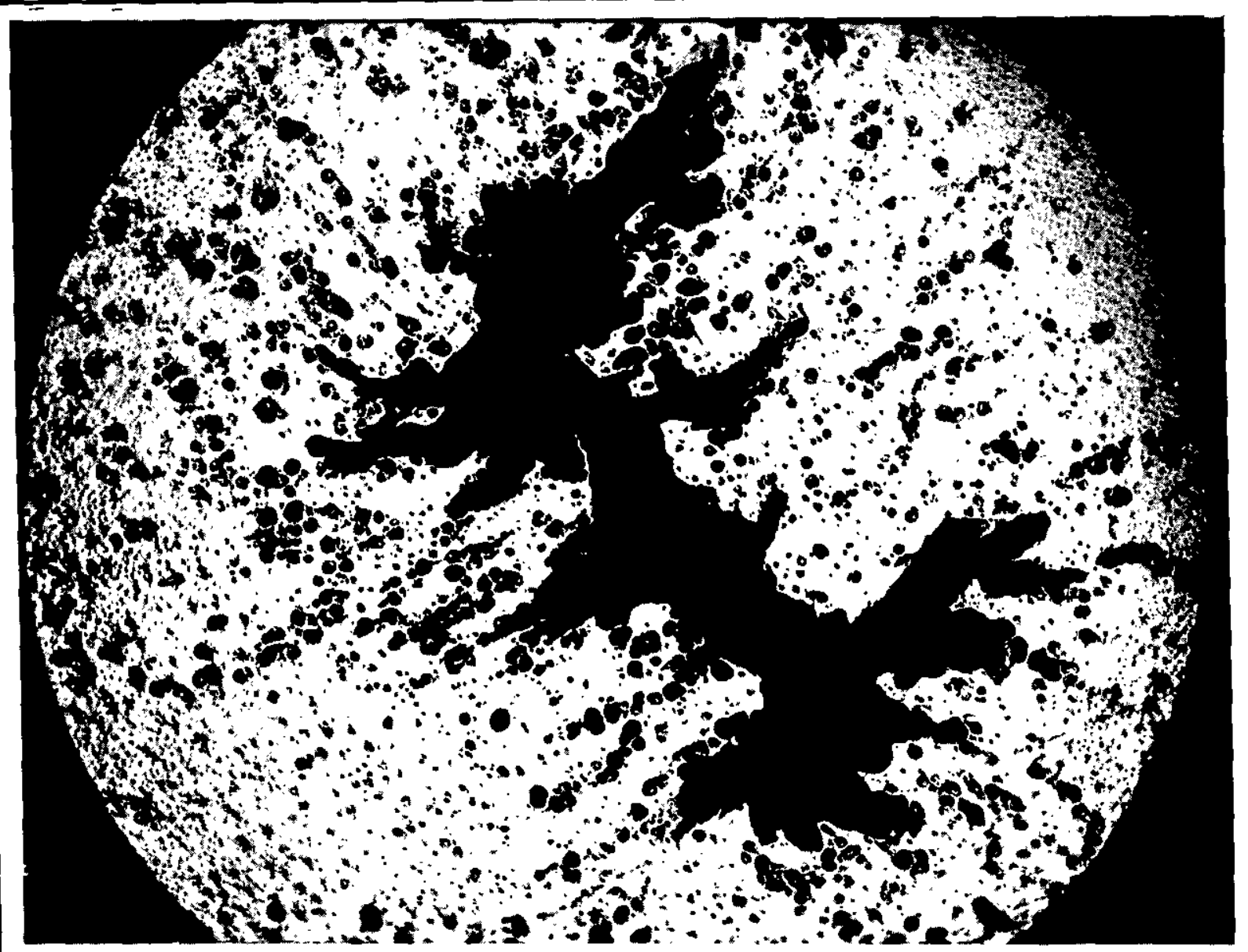

SLUG 7828-1-25 DEFECT MAGNIFIED 250 TIMES 


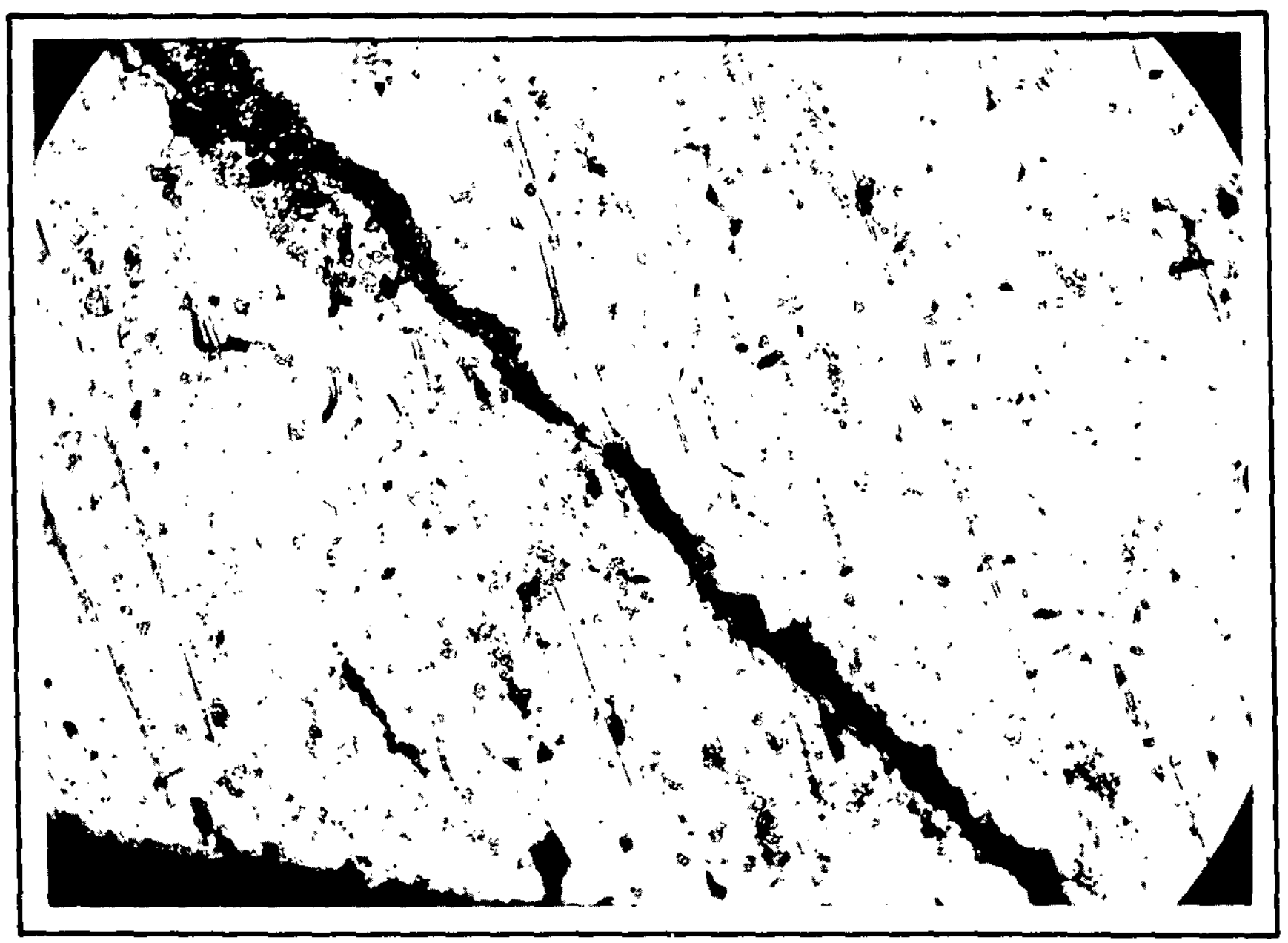

SLUG 8051-3-17 DEFECT MAGNIFIED 150 TIMES 

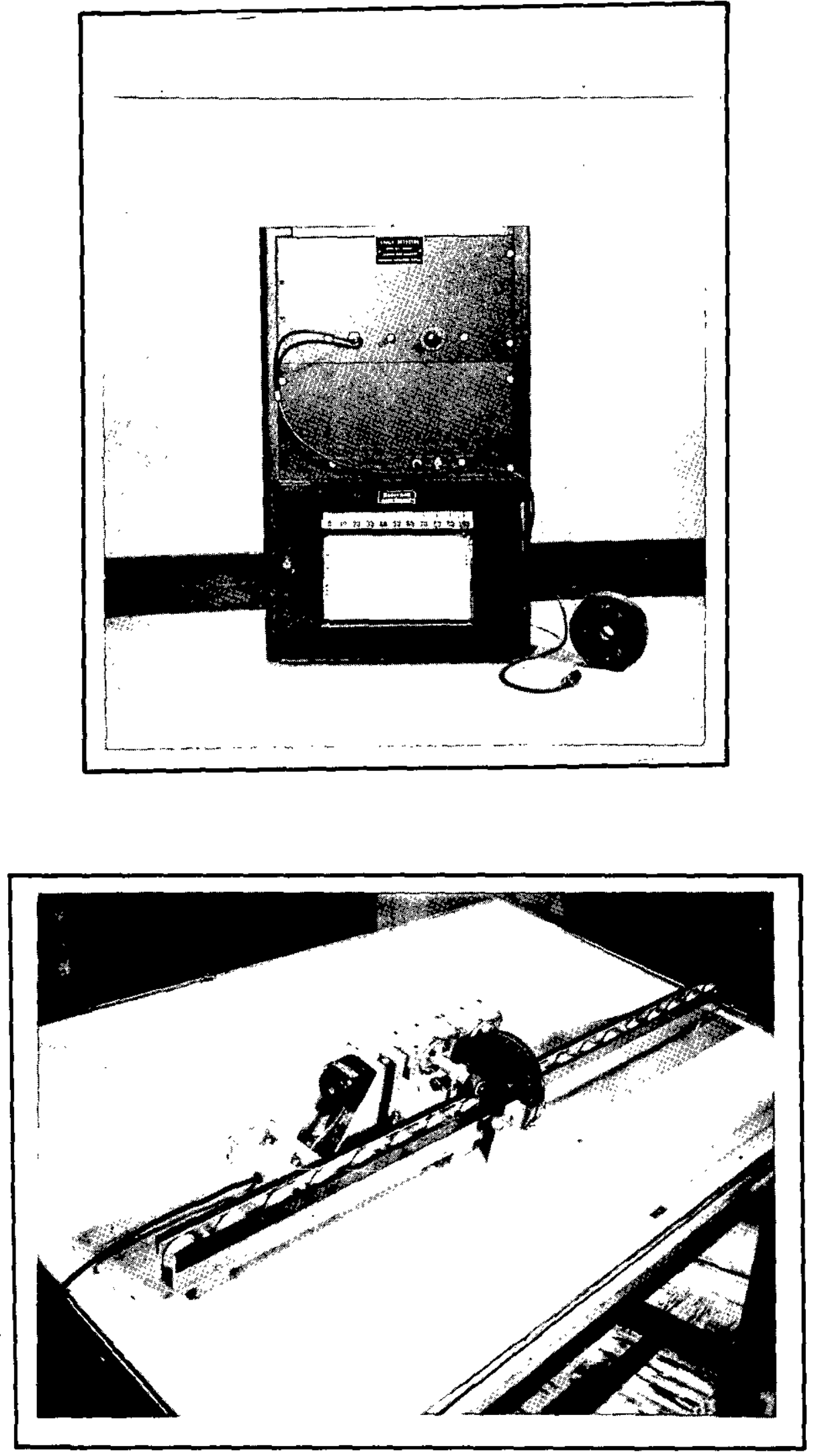

¿EQUIPMENT ASSEMBLY

URGLASSHEDED 


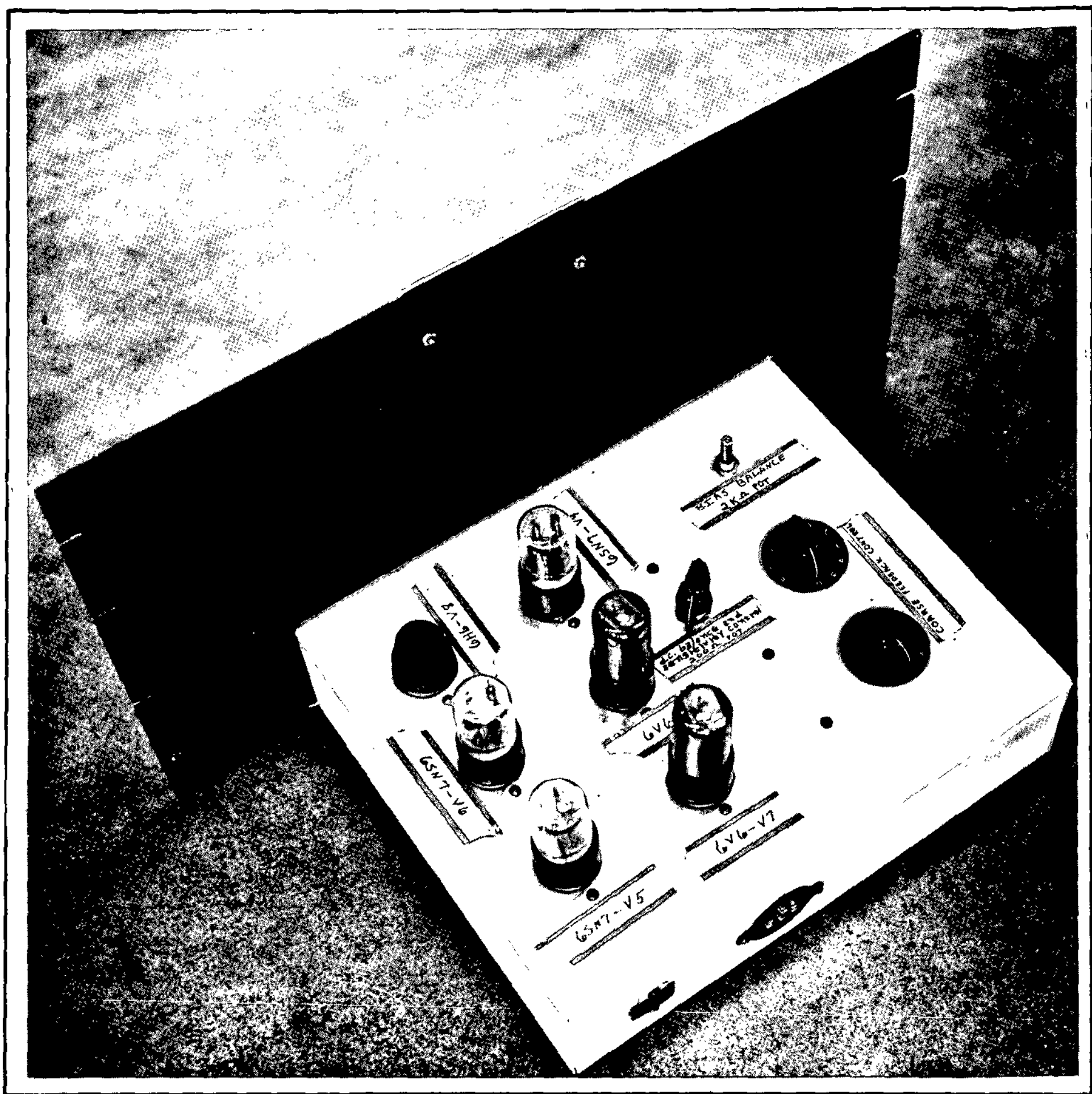

EQUIPMENT CHASSIS 


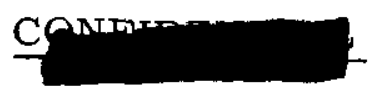

$\underline{\text { Figure } 11} \varnothing$

\section{URCEASSERED \\ DP -68 \\ Page 23}

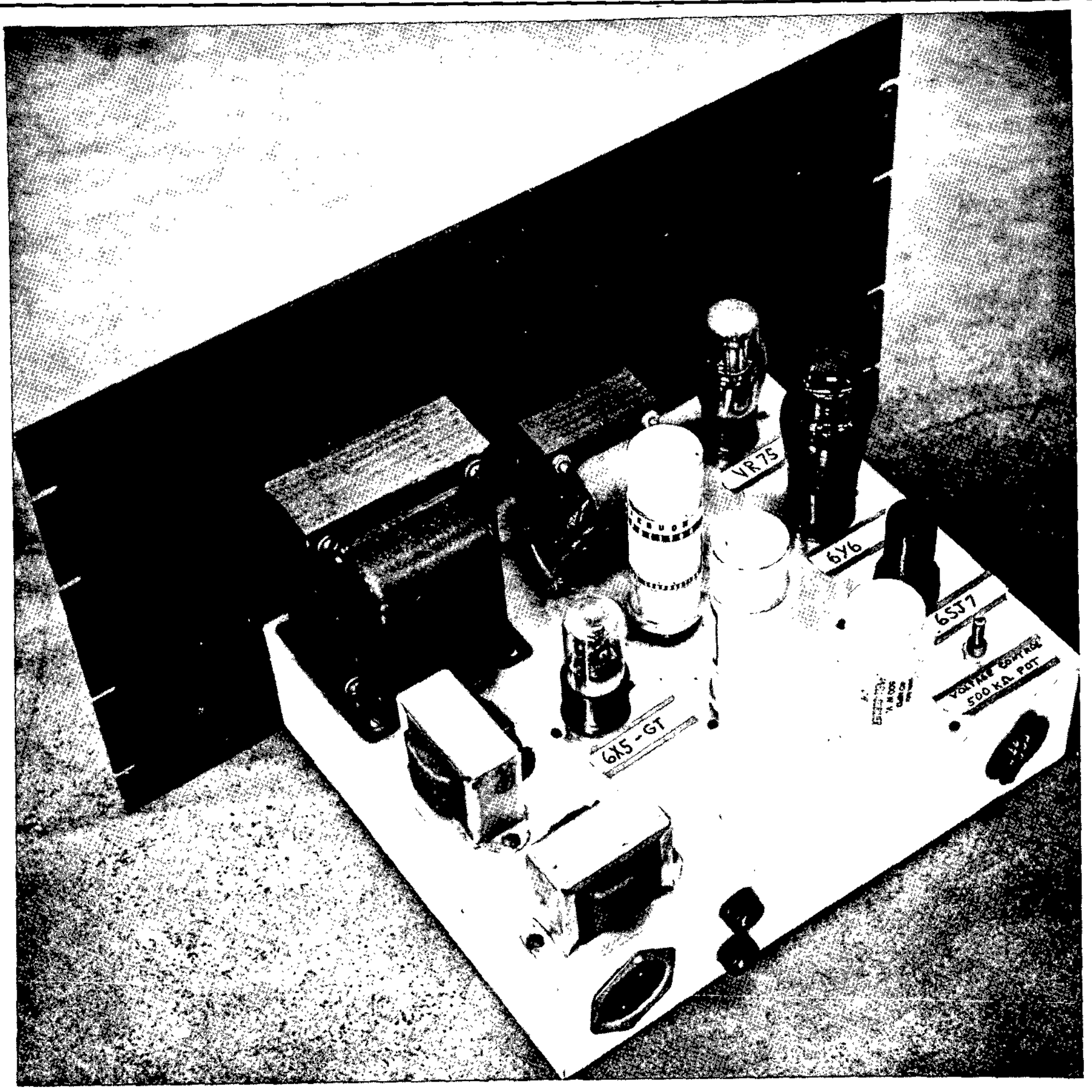

EQUIP MENT CHASSIS 


\section{DECLASSIFIED \\ $\longrightarrow$}

DP -68

Page 24

\section{APPENDIX}

\section{MAINTENANCE}

No special maintenance is required. All maintenance and servicing is done with ordinary laboratory, tools. The tubes should be tested periodically. If the 6V6's are replaced, it may be necessary to adjust the 2,000 onm potentiometer to balance them. This is done by placing the circuit in operation and observing independently the wave-forms across the 39,000ohm resistors that serve as plate-load resistors for the 6V6's. This must be done with a scope which has an aboveground input. The two wave-forms should be of the same amplitude and undistorted.

The Brown recorder contains a dry-cell battery which must be replaced periodically. Exhaustion of the cell is indicated by a pointer on the left side of the recorder.

Defective components can be localized by making routine voltage checks using the circuit diagram shown in Figure 2 . 